\title{
Bare en sykehjemslege
}

\author{
- Jeg har alltid digget disse gamle menneskene, de er en herlig pasientgruppe, sier Pernille Bruusgaard. \\ Hun har ikke valgt minste motstands vei når hun som overlege alene ved et stort sykehjem i tillegg \\ kjemper for sykehjemsmedisinens rett og sykehjemslegenes status.
}

Vi har funnet en ledig lomme i timeplanen og treffes på Smestadhjemmet en ettermiddag i september. Men hvor skal vi sitte? I storstuen er det Prøysen-ettermiddag, i aktivitetsstuen er det tirsdagsbridge og på møterommet er det møte. Ute er det blitt for kaldt. Pernille Bruusgaard fyker fra rom til rom mens den hvite legefrakken flagrer bak henne.

- Jeg trodde aldri det skulle bli vanskelig å finne et rolig sted å sitte. Men det er jo fint at det skjer så mye her, sier hun.

Det begynte da hun var 14 år og søkte kommunen om dispensasjon for å være hjemmehjelp. Mange år senere endte Oslojenta som overlege ved Smestadhjemmet, et sykehjem med 112 beboere på Oslos beste vestkant. Men selv som datter av professor og trygdemedisiner Dag Bruusgaard og barnebarn av jordmorpioner og abortforkjemper Chris Bruusgaard var det ingen selvfølge at hun skulle bli lege. Først måtte hun studere andre ting og utelukke for seg selv at det var forventninger hjemmefra som styrte. Da hun bestemte seg for medisinstudiet ble det $\mathrm{i}$ barndommens sommerby København. Turnustjenesten derimot, ville hun avtjene i Norge.

- I Danmark løp turnuslegene rundt og la venefloner, skrev planlagte innleggelsesjournaler og hadde lite behandlingsansvar. Jeg hadde hørt at den norske turnustjenesten var mye barskere. Egentlig ønsket jeg meg helt nord, til mest mulig ansvar, men kom ikke lenger enn til Namsos og Geilo, sier hun.

Den utfordringssøkende unge turnuslegen ble fornøyd likevel. Geilo var mye mer usentralt enn hun hadde trodd, det var 2-3 timer til nærmeste sykehus og en dag i uken hadde hun tjeneste på sykehjemmet, som var turnuslegedrevet. Det var en utfordring. Med utskiftning av lege hvert halvår var det dårlige rutiner for medisinering og journalføring, og ingen av legene der kjente pasientene. Det var likevel stas når hun kom på besøk, og for Pernille var det den beste dagen i uken.

- På den lille demensavdelingen hadde de bakt kake og dekket på med sitt fineste porselen når doktoren kom, minnes hun.

\section{Krefter til å flytte fjell}

Pernille Bruusgaard har en tendens til å tro at hennes entusiasme smitter og at folk blir glad når hun er så engasjert. Noen ganger blir hun skuffet, og mottakelsen hun fikk på Ullevål sykehus er ett eksempel. Hun trodde at hennes ønske om å bli geriater ville bli tatt imot med åpne armer og rød løper. Men nei, der hadde de ikke noen assistentlegestilling ledig.

Pernille ville bo i Oslo så hun sendte ut en generell søknad til hovedstadens sykehus, der overskriften lød «Trenger dere et friskt pust på avdelingen?». Hun fikk napp på anestesiavdelingen ved Radiumhospitalet. Senere har hun vært innom Oslo legevakt, Aker sykehus, Nasjonalt kunnskapssenter for helsetjenesten, Frelsesarmeens rusomsorg og studenthelsetjenesten. Hun var på nippet til å reise ut med Leger Uten Grenser, men var ikke sikker på om drivkraften var den riktige. Da hun ble med i kvinnenettverket Damenes Tale, skrev hun om seg selv: «Jeg føler jeg har krefter og engasjement til å flytte fjell, men leter fortsatt etter fjell som bør flyttes.»

- Nå har jeg funnet fjellet, sier hun.

Det første som slo henne da hun kom til Smestadhjemmet i 2006, var at nærmere Leger Uten Grenser i Norge kommer man ikke.

- Her var det ingen opplæring, ingen rutiner for jobben min, lite medisinsk utstyr og manglende journalnotater, og for mye av medisineringen og behandlingen var gjort over telefon de siste årene. Det var et voldsomt ansvar å påta seg. Jeg har relativt bred erfaring, men jeg har aldri vært med på noe liknende, sier Bruusgaard oppgitt.

- Er situasjonen spesiell for dette sykehjemmet?

- Nei, jeg tror det har vært ganske gjengs, og det er nok slik mange steder fortsatt.

\section{Karrieremessig blindvei}

Pernille Bruusgaard er profilert i mediene som motstander av overmedisinering av eldre og forkjemper for egne sykehjemsleger. Hun mener det er viktig at legene er fysisk til stede, for å bli kjent med pasientene og personalet, samarbeide med pårørende og påvirke institusjonskulturen.

- Mitt overordnede mål er at sykehjem skal bli en helseinstitusjon som befolkningen føler seg trygg på at gir god og riktig behandling og pleie når man ikke lenger kan ta vare på seg selv. Sykehjemsmedisin er svært krevende, og jeg er overbevist om at vi trenger sykehjemsleger på fulltid som kan drive fagutvikling og forskning, sier Bruusgaard.

Men fulltidssykehjemsleger er ikke ivaretatt $\mathrm{i}$ dagens spesialistutdanningssystem. Til tross for at en sykehjemslege behandler sykdommer i alle organsystemer og tar vanskelige etiske beslutninger, gir ikke praksis på sykehjem uttelling i forhold til spesialistutdanningen. Spesialister

i allmennmedisin som velger å jobbe fulltid i sykehjem mister sin spesialitet etter fem år.

- For meg er det å jobbe her en blindvei karrieremessig. Jeg får null uttelling uansett om jeg skulle velge å bli geriater eller allmennlege i ettertid. Jeg har jobbet hardt for å synliggjøre denne problemstillingen, men det virker som om Legeforeningen nå har forstått at dette må det endres på.

\section{Seponering er mirakelmedisin}

Pernille Bruusgaard har tatt grep. Hun har innført pårørendesamtaler og tar imot medisinstudenter. Siden hun kom til Smestadhjemmet er bruken av sykebesøk utenom arbeidstid redusert med $65 \%$, og medisinbruken er redusert med $40 \%$. Hun har eksempler på pasienter som har gått fra ni til null daglige medisiner, og er friskere og mer oppegående enn de har vært på lenge. Hun ser hva søkelys på medisinering og seponering gjør. På sykehjem i Norge bruker en gjennomsnittlig pasient omtrent seks faste legemidler, ofte blir medisineringen forlenget helt unødig, og ofte gir dette mer plager enn lindring.

- Pasienter blir gitt antidepressiver, antipsykotikum og sovetabletter for at de skal kunne bo hjemme så lenge som mulig, og når de får hjerteinfarkt, blir de gitt blodtrykksmedisiner og vanndrivende. Men ingen forteller dem når de kan slutte, og så sitter de her døsige, slappe og dehydrerte, med et blodtrykk som er lavere enn mitt, og orker slett ikke mat etter å ha begynt dagen med ni tabletter i ulike størrelser, farger og fasonger. Du kan jo tenke deg selv, sier Bruusgaard.

Hun forsøker å finne sammenhengen mellom medisinene og det pasienten opplever som sitt problem. Ofte gir det forbløffende resultater.

- Medisinsk sett er det kjempegøy å ta 


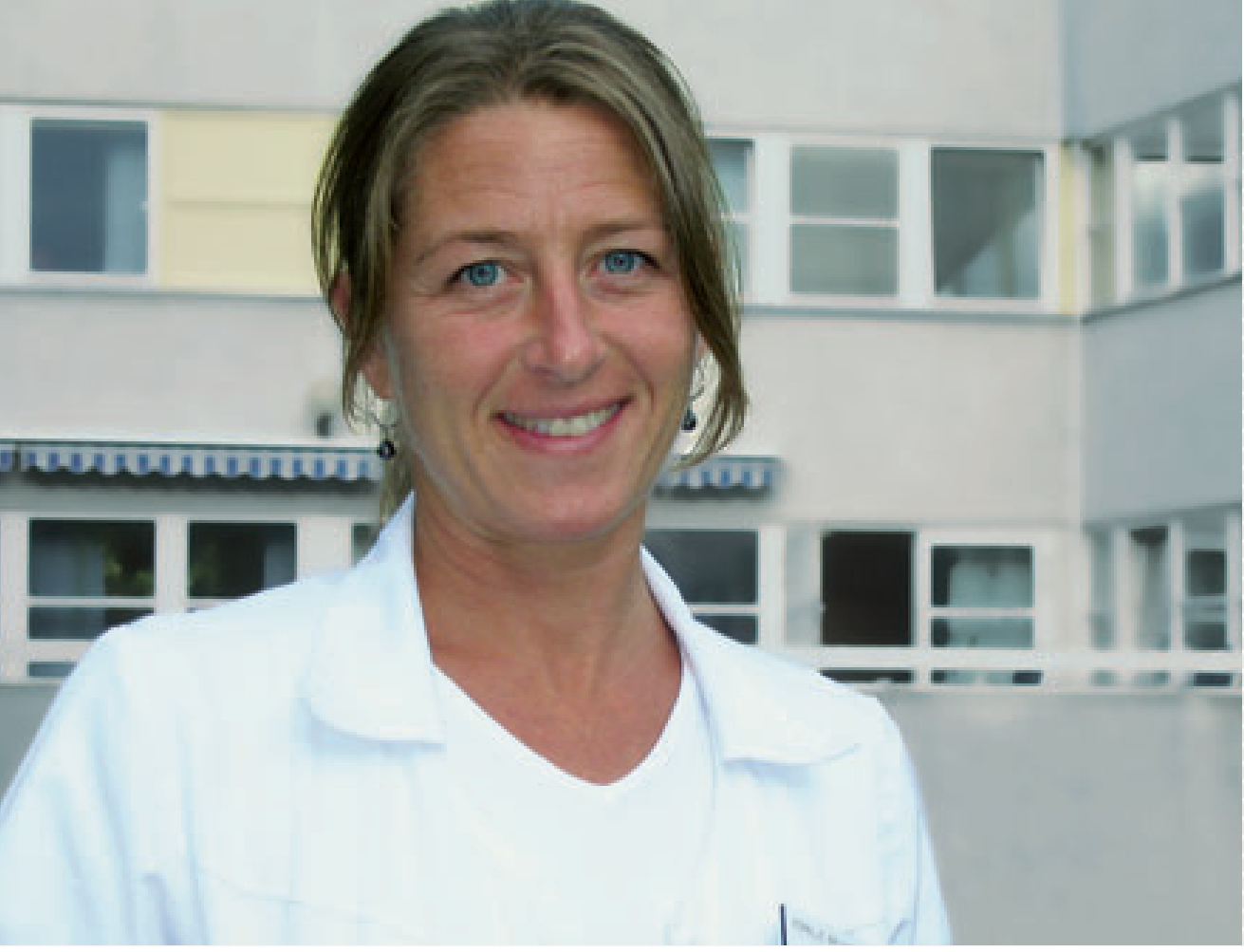

bort medisiner og få folk opp av rullestolen og rundt Smestaddammen for første gang på to år. Jeg har nesten ikke vært borti maken til mirakelmedisin, selv om jeg har jobbet både på anestesiavdeling og legevakt, sier Bruusgaard.

De gamle trenger først og fremst trygghet, pleie og omsorg, mener hun. - Mange kvikner til bare av det. Man må trappe opp og trappe ned, være nær dem. De bør slippe å sendes inn og ut av sykehus, korttidsopphold på flere ulike sykehjem og overbehandling langt inn i døden. Der synes jeg det gjøres til tider grove overtramp mot skrøpelige, demente pasienter som ikke kan ytre egne behov, sier hun.

\section{Likestilling anno 2010}

Hverdagen som sykehjemslege er ingen dans på roser. Det er ikke alltid at pasientens behov, de pårørendes ønske og hennes vurderinger stemmer overens. Samarbeidet med Sykehjemsetaten er anstrengt og kampen for alt hun tror på tar mye tid og energi. Et godt samarbeid med lokalsykehuset Diakonhjemmet og dyktige og selvstendige sykepleiere har vært viktig. Hun sier hun er helt avhengig av sykepleiernes kompetanse og tilstedeværelse og har stor respekt for jobben de gjør. Samtidig har hun god støtte fra venner og familie.

- Det er flere personer som er viktige for meg, og som støtter meg når ting er vanskelige. Faren min, kjæresten min og Svein Aarseth i Oslo legeforening, for ikke å glemme kollega og fagutviklingssykepleier Lillan Pahle ved Smestadhjemmet. Uten dem hadde jeg kanskje gitt opp, sier hun.

Bruusgaard understreker likevel at hverdagen ved et norsk sykehjem er full av gode historier som ikke kommer frem i mediene. De gamle bærer med seg mye spennende levd liv og opplevelser, de har humor og varme og ærlighet. Det finnes overraskende mye liv nær døden.

- Med årene blir man på en måte mer seg selv, og mindre opptatt av å justere sin per- sonlighet. Her får du høre det, og det synes jeg er utrolig befriende, humrer hun.

I tillegg til full stilling ved sykehjemmet holder Pernille Bruusgaard foredrag, deltar i fagutviklingsgrupper og jobber aktivt ut mot medier og politikere for å profilere og rekruttere til sykehjemsmedisinen. Hun er hovedtillitsvalgt for sykehjemslegene i Oslo kommune og styremedlem i Oslo legeforening. Opphetede debatter er hun ikke redd for, enten det dreier seg om kampen for fulltidssykehjemsleger eller likestilling. Hun vakte både begeistring og harme da hun gikk på talerstolen under et årsmøte i Norsk forening for allmennmedisin og kritiserte at påfallende mange av toppvervene ble besatt av menn. Halve salen besto jo av kvinner.

- Likestilling er absolutt et tema i 2010, ja. Jeg opplever at kvinner fortsatt må bevise mer enn menn. Menn kan komme slengende uforberedt til et møte og likevel få respekt og posisjon - bare fordi de er menn. Jeg opplever stadig at jeg sier noe som gjentas på en litt annen måte av en mannlig kollega som er 15 år eldre enn meg, så sitter alle og nikker og er så enig. Det er provoserende, sier Bruusgaard.

- Er du selv blitt hindret på noen måte fordi du er kvinne?

- Jeg tror ikke jeg hadde blitt behandlet slik av Oslo kommune hvis jeg var mann. Der møter jeg lite forståelse og anerkjennelse for mitt arbeid.

\section{Kastet på glattcelle}

Samfunnsengasjementet har vært der helt siden ungdomsskolen, da venninnegjengen skulket på 8. mars for å diskutere kvinnesak og gå i tog. Pernille og venninnene kan stolt fortelle at de ble buret inne sammen med blant andre Stein Lillevolden i 1985. De var tenåringer og deltok $\mathrm{i}$ en ulovlig demonstrasjon mot salg av olje til Sør-Afrika og for løslatelse av Nelson Mandela. Fengselsoppholdet varte bare noen timer, og hjemme

\section{Pernille Bruusgaard}

\author{
Født i Oslo 1968 \\ - Cand.med. Københavns universitet \\ 1999 \\ - Overlege, Smestadhjemmet i Oslo \\ - Tillitsvalgt for sykehjemslegene \\ i Oslo kommune \\ - Styremedlem i Oslo legeforening
}

Foto Eline Feiring

vanket det mer begeistring enn kjeft. Engasjement var bra, så lenge glattcelle ikke ble en vane.

Det er vanskelig å se for seg, men Pernille Bruusgaard kan ta det med ro. Hun elsker å gå en hel dag hjemme i pysjen, og hun sitter gjerne ut i de små timer i livsfilosofiske samtaler med kjæresten og gode venner. Hun griper like gjerne natten som dagen. Joggegruppene før frokost på seminarer grøsser hun av. For et nattmenneske er det vanskelig nok å karre seg opp til frokost. Men altså, vi snakker ikke latsabb her. Uten bil er det sykkelen eller beina som tas i bruk, og du skal ikke se bort fra at du treffer henne på snowboard i Alpene.

Privat er likevel ikke et ord som faller meg inn i samtale med Pernille Bruusgaard. Nesten uansett hva jeg spør om, vender hun tilbake til sykehjemsmedisinen. Antakelig drømmer hun om det om natten. Det er blitt hennes livsprosjekt.

- Vennene dine beskriver deg som humoristisk, omsorgsfull, omtenksom, selvransakende, pågående og skånsom. Er du enig i den beskrivelsen?

- Jeg er opptatt av å være et helt menneske, så ærlig som jeg kan, jeg er glad $i$ alle typer følelser og det er i kontrastene jeg kjenner at jeg lever. Jeg tror det er en styrke som sykehjemslege at man har kontakt med egen angst, smerte, ensomhetsfølelse, redselen for å bli forlatt. Det er jo veldig mye følelser på et sykehjem, både blant pasientene, pårørende og ansatte. - Gråter du ofte på jobb?

- Å ja, jeg kan lett felle en tåre. Når jeg ser disse gamle ekteparene som tar farvel etter et langt liv sammen, bøyer seg ned og kysser hverandre. Jeg blir rørt bare av å snakke om det, døden kan være så vakker, sier hun.

Øynene blir blanke. Jeg tror henne.

\section{Eline Feiring}

eline.feiring@legeforeningen.no Tidsskriftet 